Nicola M. Hall • Bocary Kaya · Jan Dick · Ute Skiba •

Amadou Niang $\cdot$ Ramadjita Tabo

\title{
Effect of improved fallow on crop productivity, soil fertility and climate-forcing gas emissions in semi-arid conditions
}

Received: 12 November 2004 / Revised: 23 May 2005 / Accepted: 23 May 2005 / Published online: 12 July 2005

(C) Springer-Verlag 2005

\begin{abstract}
The impacts of fallow on soil fertility, crop production and climate-forcing gas emissions were determined in two contrasting legumes, Gliricidia sepium and Acacia colei, in comparison with traditional unamended fallow and continuous cultivation systems. After 2 years, the amount of foliar material produced did not differ between the two improved fallow species; however, grain yield was significantly elevated by $55 \%$ in the first and second cropping season after $G$. sepium compared with traditional fallow. By contrast, relative to the unamended fallow, a drop in grain yield was observed in the first cropping season after $A$. colei, followed by no improvement in the second. G. sepium had higher foliar N, K and $\mathrm{Mg}$, while $A$. colei had lower foliar $\mathrm{N}$ but higher lignin and polyphenols. In the third year after fallow improvement, a simulated rainfall experiment was performed on soils to compare efflux of $\mathrm{N}_{2} \mathrm{O}$ and $\mathrm{CO}_{2}$. Improved fallow effects on soil nutrient composition and microbial activity were demonstrated through elevated $\mathrm{N}_{2} \mathrm{O}$ and $\mathrm{CO}_{2}$ efflux from soils in G. sepium fallows compared with other treatments. $\mathrm{N}_{2} \mathrm{O}$ emissions were around six times higher from this nitrogen-fixing soil treatment, evolving $69.9 \mathrm{ngN}_{2} \mathrm{O}-\mathrm{N}$ $\mathrm{g}^{-1}$ soil $\mathrm{h}^{-1}$ after a simulated rainfall event, compared with only 8.5 and $4.8 \mathrm{ngN}_{2} \mathrm{O}-\mathrm{N} \mathrm{g}^{-1}$ soil h${ }^{-1}$ from soil under traditional fallow and continuous cultivation, respectively. The findings indicate that selection of improved fallows for short-term fertility enhancement has implications for regional $\mathrm{N}_{2} \mathrm{O}$ emissions for dry land regions.
\end{abstract}

N. M. Hall $(\bowtie) \cdot$ J. Dick · U. Skiba

Centre for Ecology and Hydrology Edinburgh,

Bush Estate, Penicuik,

Midlothian, EH26 0QB, UK

e-mail: hall@ceh.ac.uk

B. Kaya $\cdot$ A. Niang

The World Agroforestry Centre, ICRAF Sahel Program,

P.O. Box 320 Bamako, Mali

R. Tabo

International Crops Research Institute for the Semi Arid Tropics,

ICRISAT Niamey,

P.O. Box 12404 Niamey, Niger
Keywords Improved fallow $\cdot$ Crop yield $\cdot$ Foliar composition · Nitrous oxide

\section{Introduction}

Improved fallow describes a system of planting with fastgrowing species specifically selected for their fertilityenhancement properties during a short-duration fallow period, while often providing other benefits, including improved fodder and fuel wood supply. Improved fallows have the potential to increase overall crop yields, while also offering services such as maintenance of microbial and insect diversity (Badiane et al. 2001; Sileshi and Mafongoya 2003) and buffering against nutrient leaching (Chikowo et al. 2004). Fast-growing leguminous nitrogen-fixing trees have been highlighted as promising fallow species, showing up to threefold improvements in crop yields compared with traditional fallow (Kaya and Nair 2001; Snapp et al. 1998). Studies indicate that improved fallows have beneficial effects on key components of soil fertility, including $\mathrm{N}$ availability (Ikerra et al. 2001); however, $\mathrm{N}_{2} \mathrm{O}$ emissions following biomass incorporation from these tree-improved fallows have yet to be determined. It is important that emissions from these systems be estimated since they may account for a significant $\mathrm{N}$ loss from dry land agroecosystems, as well as having a large contribution to climate-forcing gas budgets for semi-arid regions. More information on trace gas emissions, including $\mathrm{N}_{2} \mathrm{O}$ and $\mathrm{CH}_{4}$, is required to determine the benefits of agricultural practices such as agroforestry (Albrecht and Kandji 2003).

With increasing research on the potential for $\mathrm{C}$ storage in the terrestrial biosphere for climate mitigation, it has been proposed that agricultural land may potentially serve as a considerable C sink. Palm et al. (2002) provide data from South American managed tree systems in the humid tropics, which suggested that agroforestry had lower $\mathrm{N}_{2} \mathrm{O}$ emissions than secondary forest, which may be partly explained by the more efficient nutrient recycling in younger systems. Thus far, equivalent studies are lacking for the semi-arid tropics. Studies on the effect of fertility 
management show greater $\mathrm{N}_{2} \mathrm{O}$ emissions after incorporation of organic material into soils (Baggs et al. 2000), and that replacing traditional fallow with improved fallow systems increases $\mathrm{N}_{2} \mathrm{O}$ emissions during the rainy season (Millar et al. 2004). As with studies in temperate regions, factors such as rainfall play an important role in determining the amount and timing of $\mathrm{N}_{2} \mathrm{O}$ efflux. The aim of this study was to examine the effect of nitrogen-fixing tree species on crop productivity, soil fertility and $\mathrm{N}_{2} \mathrm{O}$ emissions from a tropical semi-arid agro-ecosystem. We report here some findings from an improved fallow experiment carried out from 2000 to 2003 by the International Centre for Research in Agroforestry (ICRAF)/International Crops Research Institute for the Semi Arid Tropics (ICRISAT) partnership at the Samanko research station, Mali.

\section{Materials and methods}

Site selection

The site is part of an improved fallow experiment established by ICRAF Sahel in July 2000, using coppicing agroforestry species at the ICRISAT-Mali field station at Samanko $\left(12^{\circ} 54^{\prime} \mathrm{N}, 08^{\circ} 04^{\prime} \mathrm{W}, 331 \mathrm{~m}\right.$ a.s.l.) — rainfall approximately $1,000 \mathrm{~mm}$ per annum, annual average temperature $27^{\circ} \mathrm{C}$. The experiment was designed to examine indicators of growth and soil improvement in coppicing agroforestry species. Container-sown seedlings were planted in the field in July 2000 at $0.75 \times 0.50-\mathrm{m}$ spacing in a well-prepared seedbed in a randomised block experiment. The soils at the station are light, poor in nutrients and organic matter $(0.5 \%)$ and have low $\mathrm{pH}(5.0-6.1)$. They are classified as alfisols (or leached tropical ferruginous soils without concretions). After 2 years of growth (June 2002), the aboveground leafy biomass and litter fall from all plots were quantified before incorporation into the soil to serve as a nutrient source for the subsequent sorghum crop (ICSV 400). Cultivation was continued for successive seasons to assess the species-specific residue effect on crop yields. The data analysed here were collected at the second year of tree growth from the most productive (Gliricidia sepium) and the least-performing (Acacia colei) treatments, and a comparison was made with continuous cultivation of sorghum and traditional unamended fallow treatments in two successive cropping cycles. The traditional practice for sorghum cultivation in the region is sowing in a well-prepared seedbed followed by raising ridges around the crop a month or 45 days later. This creates distinguishable ridges and mid-ridges spaced at approximately $0.75-\mathrm{m}$ intervals in the plot, with a ridge-to-trough depth of approximately $30 \mathrm{~cm}$.

Soil respiration in the field

Soil respiration rate $\left(\mathrm{g} \mathrm{CO}_{2} \mathrm{~m}^{-2} \mathrm{~h}^{-1}\right)$ was measured in situ (PP System EGM2 Soil Respiration System with SRC-1 chamber) on 28th January 2004 during the dry season on bare ground, on the cultivated ridge or between the ridges (mid-ridge) in all treatments. Four measurements were taken in each of two blocks per treatment, with duplicates in the ridge and mid-ridge areas.

\section{Soil and foliar analysis}

A sample of the top $0-20 \mathrm{~cm}$ of soil was collected in January 2004 during the dry season from three blocks each of the four treatments. The ground in all blocks retained visible cultivation ridges and was found to show differences in soil respiration between the ridge and mid-ridge areas immediately prior to sampling; therefore, within each plot, three samples where randomly selected from the top of the ridge and three from between the ridges. The samples were bulked, air-dried and transported to the Centre for Ecology and Hydrology (CEH), Edinburgh, UK. All soil samples were sieved $(<710-\mu \mathrm{m}$ mesh size $)$ and thoroughly mixed prior to subsampling for analysis and experiments. Soil organic $\mathrm{C}$ was estimated by loss on ignition, following the methodology of Rowell (1994), as recommended for sandy soils. Foliar analysis of $\mathrm{N}$ and $\mathrm{P}$ was performed on three air-dried samples by acid digestion using the Kjeldahl method (Okalebo et al. 2002). Complete oxidation by the Kjeldahl method followed by spectrometry analysis (Okalebo et al. 2002) was used for $\mathrm{K}, \mathrm{Ca}$ and $\mathrm{Mg}$. Per cent total soluble polyphenols (PPs) was determined by the Folin-Ciocalteau method (Allen et al. 1974), while Goering and Van Soest (1970) was used for the per cent lignin.

Soil respiration and $\mathrm{N}_{2} \mathrm{O}$ flux after simulated rainwater and substrate addition

Aliquots of $60 \mathrm{~g}$ of air-dried soil were placed into clear Perspex columns (20-cm height $\times 5$-cm diameter), which were sealed at the base (as described by Dick et al. 2001). In the headspace, inlet and outlet apertures were inserted at staggered heights on opposite sides and fitted with a three-way tap. A total of 12 repacked soil columns were established (three replicate columns each of four soil treatments). The repacked soil columns were incubated at $20^{\circ} \mathrm{C}$ and analysed for soil moisture and soil chemical properties. Additional columns without soil were as follows: (1) empty, (2) glucose-based substrate solution $(80 \%$ glucose, $13 \%\left(\mathrm{NH}_{4}\right)_{2} \mathrm{SO}_{4}$ and $2 \% \mathrm{KH}_{2} \mathrm{PO}_{4}$ by mass) or (3) distilled water, were included as controls for $\mathrm{N}_{2} \mathrm{O}$ and $\mathrm{CO}_{2}$ efflux measurements. Synthetic rainwater, based on the rain chemistry measured at Lake Malawi (Talling and Lemoalle 1998), was added to the repacked soil cores. A total of $19 \mathrm{~g}$ of synthetic rainwater (equivalent to $9.5 \mathrm{~mm}$ of rain) was added to $60 \mathrm{~g}$ air-dry soil. $\mathrm{N}_{2} \mathrm{O}$ fluxes were measured 2-3 times daily for 4 days after the initial rain event by sealing the columns with plastic lids, fitted with airtight rubber sleeves, for $60 \mathrm{~min}$. Headspace air samples 
$(10 \mathrm{ml})$ were withdrawn by syringe and analysed for $\mathrm{N}_{2} \mathrm{O}$ by electron-capture gas chromatography (Hewlett-Packard 5890X). Ambient room air was also collected at the beginning of each sample set. The $\mathrm{N}_{2} \mathrm{O}$ flux was calculated as follows:

$$
\begin{aligned}
& \mathrm{ngN}_{2} \mathrm{O}-\mathrm{Ng}^{-1} \text { soil } \mathrm{hr}^{-1} \\
& \quad=\frac{\mathrm{N}_{2} \mathrm{O}_{t_{1}}-\mathrm{N}_{2} \mathrm{O}_{t_{0}}\left(\mathrm{ng} \mathrm{m}^{-3}\right) \times \text { headspace volume }\left(\mathrm{m}^{3}\right)}{\text { mass dry soil }(\mathrm{g}) \times \operatorname{time}(\mathrm{hr})}
\end{aligned}
$$

where $t_{1}$ and $t_{0}$ represent the increase in $\mathrm{N}_{2} \mathrm{O}$ concentration during a period of $1 \mathrm{~h}$ above ambient laboratory air $(a m b)$ for the volume of the headspace in the repacked soil column.

After the $\mathrm{N}_{2} \mathrm{O}$ pulse, in response to simulated rainfall, had abated, the microbial biomass was estimated by substrate-induced soil respiration using a glucose-based substrate in solution, following the methodology published in BS-ISO-17155:2002 (BS-ISO 2002). The substrate solution was added to return the moisture content of each soil column to $80 \%$ of field capacity. $\mathrm{N}_{2} \mathrm{O}$ fluxes were measured at 18, 26 and $50 \mathrm{~h}$ after glucose addition, and $\mathrm{CO}_{2}$ respiration was measured three times daily after sealing the containers for $2 \mathrm{~min}$. Soil respiration measurements of the $\mathrm{CO}_{2}$ efflux in mg $\mathrm{CO}_{2} \mathrm{~g}^{-1}$ soil $\mathrm{h}^{-1}$ were made with a portable infrared gas analyser (LiCor Inc., Lincoln, NE, USA) in a closed system, circulating air through the sealed soil column. The following parameters were recorded from the respiration response to substrate addition: (1) the basal rate $\left(\mathrm{R}_{\mathrm{B}}\right)$, the average respiration during the stable period before addition of glucose; (2) the substrate-induced respiration $\left(\mathrm{R}_{\mathrm{S}}\right)$ as the average of values shortly after substrate addition, when respiration becomes temporarily stable (before exponential growth of microbial populations); (3) the exponential growth rate of the micro-organisms $(\mu)$, estimated from the exponential part of the response curve; and (4) the respiratory activation quotient $\left(\mathrm{R}_{\mathrm{B}} / \mathrm{R}_{\mathrm{S}}\right)$ that is the ratio of basal to substrate-induced respiration. Soil microbial biomass $C$ (SMBC) was calculated using the formula of Anderson and Domsch (1978):

$$
\begin{aligned}
\mu \mathrm{g} \mathrm{SMBC} \mathrm{g}^{-1} \text { soil }= & \left(40.04 \times \mu \mathrm{lCO}_{2}\left(\mathrm{R}_{\mathrm{S}}\right) \mathrm{g}^{-1} \text { soil }^{-1}\right) \\
& +0.37
\end{aligned}
$$

Soil was extracted with $1 \mathrm{M} \mathrm{KCl}$ and analysed for soilexchangeable $\mathrm{NH}_{4}^{+}$by using the indo-phenol method (Wetzel and Likens 2000), and $\mathrm{NO}_{3}^{-}$using a Reflectoquant $\mathrm{NO}_{3}^{-}$analysis system (Merck, Germany).

\section{Results}

Plant production and grain yield

The total woody production and the foliar biomass incorporated into the soil in 2002 after 2 years of growth, as well as the straw and grain yield of the sorghum crop grown in 2002 and 2003, are shown in Table 1. Woody biomass did not differ between the two improved fallow tree species; however, significantly more foliar biomass was produced and incorporated into the soil from $A$. colei. In the first year of cropping after fallow (2002), there was no difference in straw production between treatments. Significantly elevated grain production was found in $G$. sepium plots in comparison with the traditional fallow and continuously cultivated plots, from which grain yield was similar, while a substantially lower grain production was found in plots of $A$. colei. In the following cropping season, straw production was almost double in G. sepium plots compared with the other treatments, and grain yield was significantly higher compared with continuous cultivation plots. A. colei plots had a much improved grain yield $(176 \%)$ in the second season, while all other treatments had lower grain and straw yield in 2003. Grain yield in the continuously cultivated plots dropped by $59 \%$ between

Table 1 Total woody biomass production and foliar production, showing the amount of foliar biomass incorporated prior to crop

\begin{tabular}{|c|c|c|c|c|c|c|c|}
\hline \multirow[t]{2}{*}{ Treatments } & \multicolumn{2}{|c|}{ Fallow treatment $2000-2002$} & \multicolumn{4}{|c|}{ Sorghum yield 2002-2003 } & \multirow{2}{*}{$\begin{array}{l}\text { Soil C } 2004 \\
\text { Total loss on } \\
\text { ignition ( } \%)\end{array}$} \\
\hline & $\begin{array}{l}\text { Wood } \\
\text { production } \\
\left(\mathrm{t} \mathrm{ha}^{-1}\right)\end{array}$ & $\begin{array}{l}\text { Total foliar biomass } \\
\text { incorporation }\left(t \mathrm{ha}^{-1}\right)\end{array}$ & $\begin{array}{l}\text { Straw yield } \\
2002\left(\mathrm{~kg} \mathrm{ha}^{-1}\right)\end{array}$ & $\begin{array}{l}\text { Grain yield } \\
2002\left(\mathrm{~kg} \mathrm{ha}^{-1}\right)\end{array}$ & $\begin{array}{l}\text { Straw yield } \\
2003\left(\mathrm{~kg} \mathrm{ha}^{-1}\right)\end{array}$ & $\begin{array}{l}\text { Grain yield } \\
2003\left(\mathrm{~kg} \mathrm{ha}^{-1}\right)\end{array}$ & \\
\hline G. sepium & $13.26^{\mathrm{a}}$ & $12.18^{\mathrm{b}}$ & $8,025 \pm 606^{\mathrm{a}}$ & $1,938 \pm 256^{\mathrm{a}}$ & $3,343 \pm 309^{a}$ & $1,250 \pm 382^{\mathrm{a}}$ & $0.30 \pm 0.006^{\mathrm{a}}$ \\
\hline A. colei & $13.09^{\mathrm{a}}$ & $16.65^{\mathrm{a}}$ & $6,444 \pm 697^{\mathrm{a}}$ & $294 \pm 217^{\mathrm{c}}$ & $1,842 \pm 300^{\mathrm{b}}$ & $810 \pm 93^{\mathrm{a}, \mathrm{b}}$ & $0.24 \pm 0.006^{\mathrm{c}}$ \\
\hline $\begin{array}{l}\text { Traditional } \\
\text { fallow }^{1}\end{array}$ & $0^{\mathrm{b}}$ & $0.58^{\mathrm{c}}$ & $6,060 \pm 643^{\mathrm{a}}$ & $1,249 \pm 27^{\mathrm{b}}$ & $1,718 \pm 133^{b}$ & $810 \pm 101^{a, b}$ & $0.28 \pm 0.001^{b}$ \\
\hline $\begin{array}{l}\text { Continuous } \\
\text { cultivation }^{2}\end{array}$ & $0^{\mathrm{b}}$ & $0.21^{\mathrm{c}}$ & $5,658 \pm 838^{\mathrm{a}}$ & $1,130 \pm 152^{b}$ & $1,282 \pm 179^{\mathrm{b}}$ & $463 \pm 23^{b}$ & $0.23 \pm 0.005^{\mathrm{c}}$ \\
\hline
\end{tabular}
sowing between 2000 and 2002, sorghum straw and grain yield in

2002 and 2003, and soil total organic carbon measured by mass loss on ignition in 2004

Different letters within columns indicate significant differences found using Fisher's protected least significant difference (LSD) test

${ }^{1}$ Natural vegetation and weed incorporated at seedbed preparation

${ }^{2}$ Crop residues removed, remaining residue and weed incorporated at seedbed preparation 
2002 and 2003, which was a much higher drop than in the plots of G. sepium or traditional fallow which both dropped by around $35 \%$.

Nutrient composition of leaves and soil

The results of foliar analysis of major elements (N, P, K and $\mathrm{Mg}$ ) and nitrogenous compounds contributing to soil fertility are shown in Table 2, along with a calculation of the total $\mathrm{N}$ application. Leaves of $A$. colei had a higher level of soluble PPs and lignin than those of G. sepium or the species sampled in the other treatments. By contrast, $G$. sepium had the highest foliar $\mathrm{N}, \mathrm{P}$ and $\mathrm{Mg}$ contents. The sorghum (and weeds) sampled in the traditional fallow did not differ greatly from each other in nutrient contents. Bulked soil organic $\mathrm{C}$, as indicated by loss on ignition, was less than $1 \%$ for all plots; however, significant differences were found between treatments (Table 1), with soil under G. sepium having the highest soil organic carbon SOC, followed by traditional fallow and similarly low levels in both $A$. colei and continuously cultivated plots. Differences in SOC were particularly notable between the two treatments with trees, despite similar amounts of biomass incorporation. After the simulated rainfall event, soil $\mathrm{NH}_{4}^{+}-$ $\mathrm{N}$ levels were the highest in soils from $G$. sepium plots compared with other treatments, while soil $\mathrm{NO}_{3}^{-}-\mathrm{N}$ was higher from both the improved fallow plots (Table 3 ).

\section{Soil respiration in situ}

After an 80-s measurement cycle the soil respiration chamber measured increases in $\mathrm{CO}_{2}$ efflux, which ranged between 0.10 and $0.55 \mathrm{~g} \mathrm{CO}_{2} \mathrm{~m}^{-2} \mathrm{~h}^{-1}$. Measurement of soil respiration during the dry season on the four field treatments showed that there were significant treatment differences in between ridge sites $(p=0.04)$ but not between mid-ridges $(p=0.27)$, while differences between the ridge and mid-ridge were significant in all treatments $(p=0.02)$, with the exception of soils under G. sepium (Fig. 1). Soil samples were bulked rather than differentiated into ridge and mid-ridge types; therefore, it was not possible to make comparisons with soil organic matter content or other soil components.
Table 3 Total $\mathrm{N}_{2} \mathrm{O}$ efflux, soil $\mathrm{NO}_{3}^{-}-\mathrm{N}$ and soil $\mathrm{NH}_{4}^{+}-\mathrm{N}$ from soils after rainfall simulation event

\begin{tabular}{lcll}
\hline & $\begin{array}{l}\text { Total } \mathrm{N}_{2} \mathrm{O} \\
\text { efflux ng } \mathrm{N}_{2} \mathrm{O}-\mathrm{N} \\
\mathrm{g}^{-1} \text { soil h}^{-1}\end{array}$ & $\begin{array}{l}\mathrm{Soil} \mathrm{NO}_{3}^{-} \\
\mathrm{ug} \mathrm{NO}_{3}-\mathrm{N} \\
\mathrm{g}^{-1} \text { soil }\end{array}$ & $\begin{array}{l}\text { Soil } \mathrm{NH}_{4}^{+} \\
\mathrm{ug} \mathrm{NH}_{4}-\mathrm{N} \\
\mathrm{g}^{-1} \text { soil }\end{array}$ \\
\hline G. sepium & $69.9 \pm 27.7^{\mathrm{a}}$ & $34 \pm 5.2^{\mathrm{a}, \mathrm{b}}$ & $18.3 \pm 2.0^{\mathrm{a}}$ \\
A. colei & $10.4 \pm 2.6^{\mathrm{b}}$ & $49 \pm 10.7^{\mathrm{a}}$ & $10.5 \pm 1.2^{\mathrm{b}}$ \\
Traditional fallow & $8.5 \pm 2.6^{\mathrm{b}}$ & $20 \pm 4.8^{\mathrm{b}}$ & $11.5 \pm 1.0^{\mathrm{a}, \mathrm{b}}$ \\
Continuous culture & $4.8 \pm 1.4^{\mathrm{b}}$ & $16 \pm 4.9^{\mathrm{b}}$ & $10.5 \pm 1.2^{\mathrm{b}}$ \\
\hline
\end{tabular}

Different letters within columns indicate significant differences found using Fisher's protected least significant difference (LSD) test

$\mathrm{N}_{2} \mathrm{O}$ flux in response to simulated rainfall

No detectable $\mathrm{N}_{2} \mathrm{O}$ was emitted within the first $24 \mathrm{~h}$ after the simulated rainfall event (Fig. 2). Thereafter, soil collected from all treatment plots emitted detectable $\mathrm{N}_{2} \mathrm{O}$ between 24 and $48 \mathrm{~h}$ after the addition of the rainwater, with soil collected from $G$. sepium plots emitting detectable $\mathrm{N}_{2} \mathrm{O}$ for a further $24 \mathrm{~h}$. Total $\mathrm{N}_{2} \mathrm{O}$ emissions measured during the simulated rainfall event and a subsequent drying cycle were approximately sixfold higher from the soil samples collected in the G. sepium plots compared with the other three treatments which did not differ markedly from each other (Table 3). After 4 days of soil drying, the average moisture loss from the containers was $46.5 \%$ of the total "rainwater" added. Moisture loss did not differ in amount or rate between soil treatments. Peak $\mathrm{N}_{2} \mathrm{O}$ efflux occurred at $80 \%$ water-holding capacity for $A$. colei, traditional fallow and continuous cultivation, and at around $70 \%$ for G. sepium. After $\mathrm{N}_{2} \mathrm{O}$ efflux had subsided from all soil treatments following the rainwater pulse, a glucosebased substrate was added, and a further pulse of $\mathrm{N}_{2} \mathrm{O}$ was observed. Higher $\mathrm{N}_{2} \mathrm{O}$ peaks were observed from $A$. colei, traditional fallow and continuous cultivation samples with substrate addition than with just simulated rainfall, while a lower $\mathrm{N}_{2} \mathrm{O}$ peak was observed from $G$. sepium. Of the four soil treatments, the highest $\mathrm{N}_{2} \mathrm{O}$ peak under glucose substrate addition was from the traditional fallow treatment.

\section{Substrate-induced soil respiration}

Soil respiration was measured in response to substrate addition in tandem with $\mathrm{N}_{2} \mathrm{O}$ flux to quantify substrate-in-

Table 2 Foliar composition of major elements (nitrogen, phosphorus, potassium and magnesium) and constituents contributing to soil fertility in two coppicing agroforestry species compared with traditional fallow species and continuously cropped sorghum

\begin{tabular}{|c|c|c|c|c|c|c|c|c|c|c|}
\hline & $\begin{array}{l}\mathrm{N} \\
(\%)\end{array}$ & $\begin{array}{l}\mathrm{P} \\
(\%)\end{array}$ & $\begin{array}{l}\mathrm{K} \\
(\%)\end{array}$ & $\begin{array}{l}\mathrm{Mg} \\
(\%)\end{array}$ & $\begin{array}{l}\mathrm{PP} \\
(\%)\end{array}$ & $\begin{array}{l}\text { Lignin } \\
(\%)\end{array}$ & $\begin{array}{l}\mathrm{C} / \mathrm{N} \\
(\%)\end{array}$ & $\begin{array}{l}\mathrm{Lig} / \mathrm{N} \\
(\%)\end{array}$ & $\begin{array}{l}(\operatorname{Lig}+\mathrm{PP}) \\
(\%) / \mathrm{N}\end{array}$ & $\begin{array}{l}\text { Total } N \text { in applied } \\
\text { biomass }(\mathrm{kg} / \mathrm{ha})\end{array}$ \\
\hline G. sepium & 3.70 & 0.21 & 2.41 & 0.72 & 2.23 & 7.68 & 11.38 & 2.08 & 2.68 & 450.7 \\
\hline A. colei & 2.10 & 0.08 & 0.94 & 0.20 & 13.49 & 14.54 & 22.97 & 6.92 & 13.35 & 349.7 \\
\hline Traditional fallow & 1.70 & 0.12 & 2.78 & 0.23 & 1.32 & 5.66 & 23.41 & 3.33 & 4.11 & 9.9 \\
\hline Continuous cultivation & 2.05 & 0.11 & 2.22 & 0.37 & 1.31 & 6.29 & 19.02 & 3.07 & 3.71 & 4.3 \\
\hline
\end{tabular}

Lig Lignin, $P P$ soluble polyphenolics 


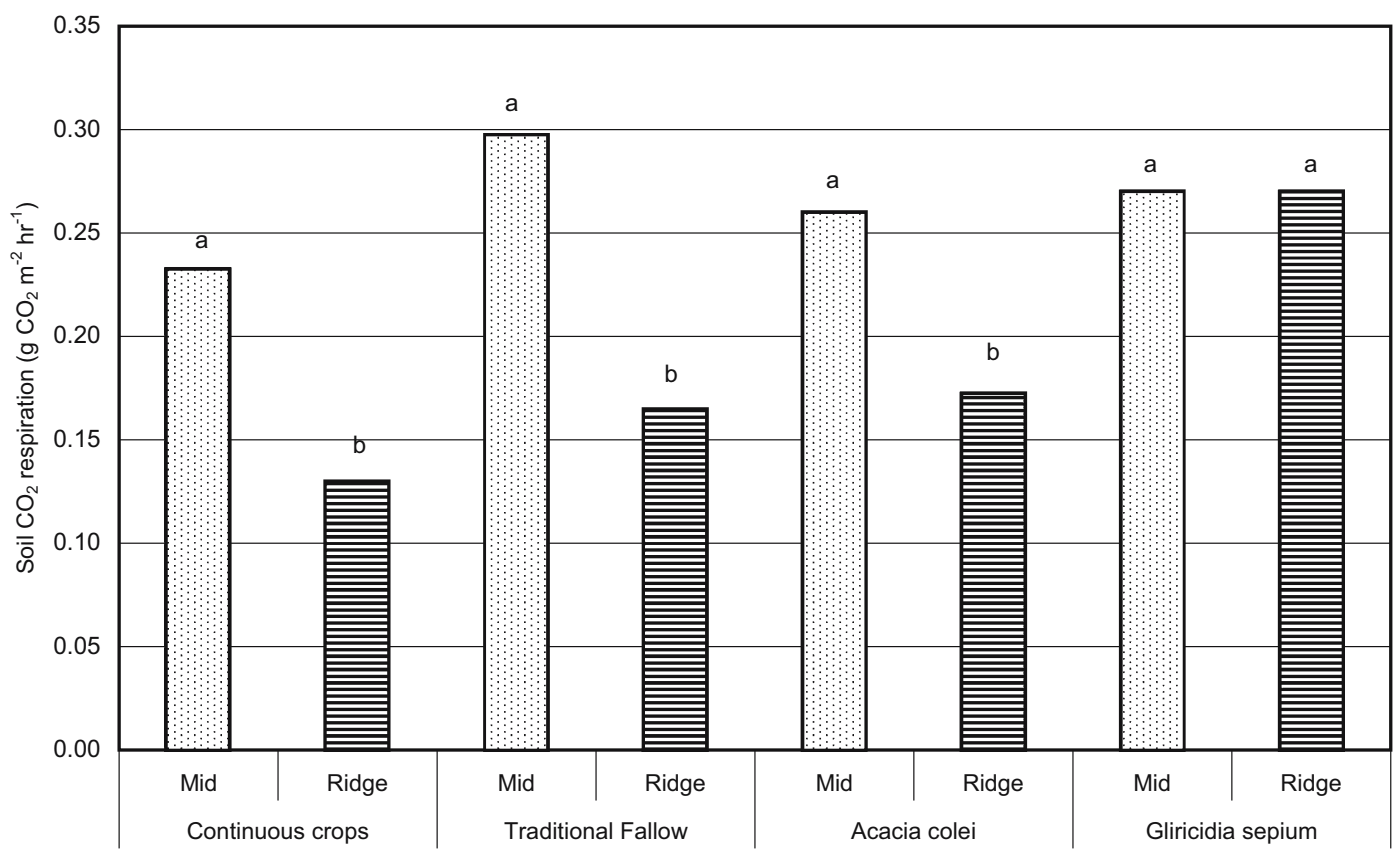

Fig. 1 Soil $\mathrm{CO}_{2}$ respiration in situ from ridged fields of improved fallow, traditional fallow and continuous cultivation

duced soil microbial activity (Fig. 2). No response in soil respiration was observed for the first $24 \mathrm{~h}$ after substrate addition, although $\mathrm{N}_{2} \mathrm{O}$ efflux increased greatly during this period. An initial increase in $\mathrm{CO}_{2}$ respiration was then observed from all treatments, indicating the first aerobic response of the soil microbial community to glucose addition which occurred when soils had dried out to a water-holding capacity of $60 \%$. The $\mathrm{R}_{\mathrm{B}}$ did not vary significantly between treatments; however, the $\mathrm{R}_{\mathrm{S}}$ was highest for $G$. sepium and lowest for continuous cultivation samples (Table 4). The ratio of $R_{B} / R_{S}$, from which is derived the respiratory activation quotient $\left(\mathrm{Q}_{\mathrm{R}}\right)$, was highest for traditional fallow and continuous culture samples, which indicates a lower level of activity of soil microbes in these treatments. A period of exponential growth of soil organisms in response to substrate addition was indicated by the parameter $\mu$, which was higher for G. sepium and lowest for continuous culture. The SMBC was estimated to be higher for G. sepium and lowest in the continuously cultivated plots.

\section{Discussion}

A comparison of the effect of planting nitrogen-fixing woody species in fallow soil with traditional fallow and continuous cultivation demonstrated that G. sepium had a significantly positive impact on the succeeding crop production. G. sepium grown in the soil for 2 years resulted in improved biomass and grain yield in sorghum, compared with $A$. colei fallow or traditional fallow over the same period, despite a similarly higher foliar biomass input to the soil from A. colei. G. sepium had higher foliar N, P and $\mathrm{Mg}$ compared with other treatments, while by contrast, $A$. colei had substantially lower levels of these nutrients and higher levels of PPs and lignin. The contrasting foliar composition of nitrogenous compounds of these two species seems to affect nitrogen mineralisation of leaf residues, and their relative immobilisation in the soil, affecting $\mathrm{N}$ availability in the following cropping season. It has previously been shown that PP and lignin content of organic material can affect the $\mathrm{N}$ release dynamics of organic fertility amendments (Palm and Sanchez 1991). High-foliar N, combined with low lignin and PPs, result in a high and immediate capacity for $\mathrm{N}$ supply, whereas low-foliar $\mathrm{N}$ and highlignin and high-PPs provide the lowest capacity for $\mathrm{N}$ supply, combined with a possible long-term immobilisation of soil N (Mafongoya et al. 1997; Palm et al. 2001). The latter category, which is described as having low resource quality, may however have long-term benefits for soil structure and organic $\mathrm{C}$ content. This has implications for species selection for improved fallows, since farmers can use information about the relative immediacy of $\mathrm{N}$ release of fallow species to make decisions about appropriate nutrient requirements for their cropping systems. Since farmers rarely have access to information about foliar composition, the foliar characteristics determined by $\mathrm{N}$, PP and lignin content have been translated into a farmerfriendly key by Giller (2000), based on leaf colour and texture.

The enhanced $\mathrm{N}$ status of the soil conferred by a $G$. sepium fallow is reflected in the higher nitrous oxide $\left(\mathrm{N}_{2} \mathrm{O}\right)$ emissions from this soil after a simulated rainfall event (Table 2). Previous studies show higher $\mathrm{N}_{2} \mathrm{O}$ emissions from soil under $\mathrm{N}$-fixing trees compared with non- $\mathrm{N}$-fixing species (Dick et al. 2001, 2004). This study demonstrates considerable variation in emissions between soil having supported two $\mathrm{N}$-fixing species, which may relate to different levels of $\mathrm{N}$ fixation. However, differences in foliar composition can play an important role in $\mathrm{N}$ availability, 


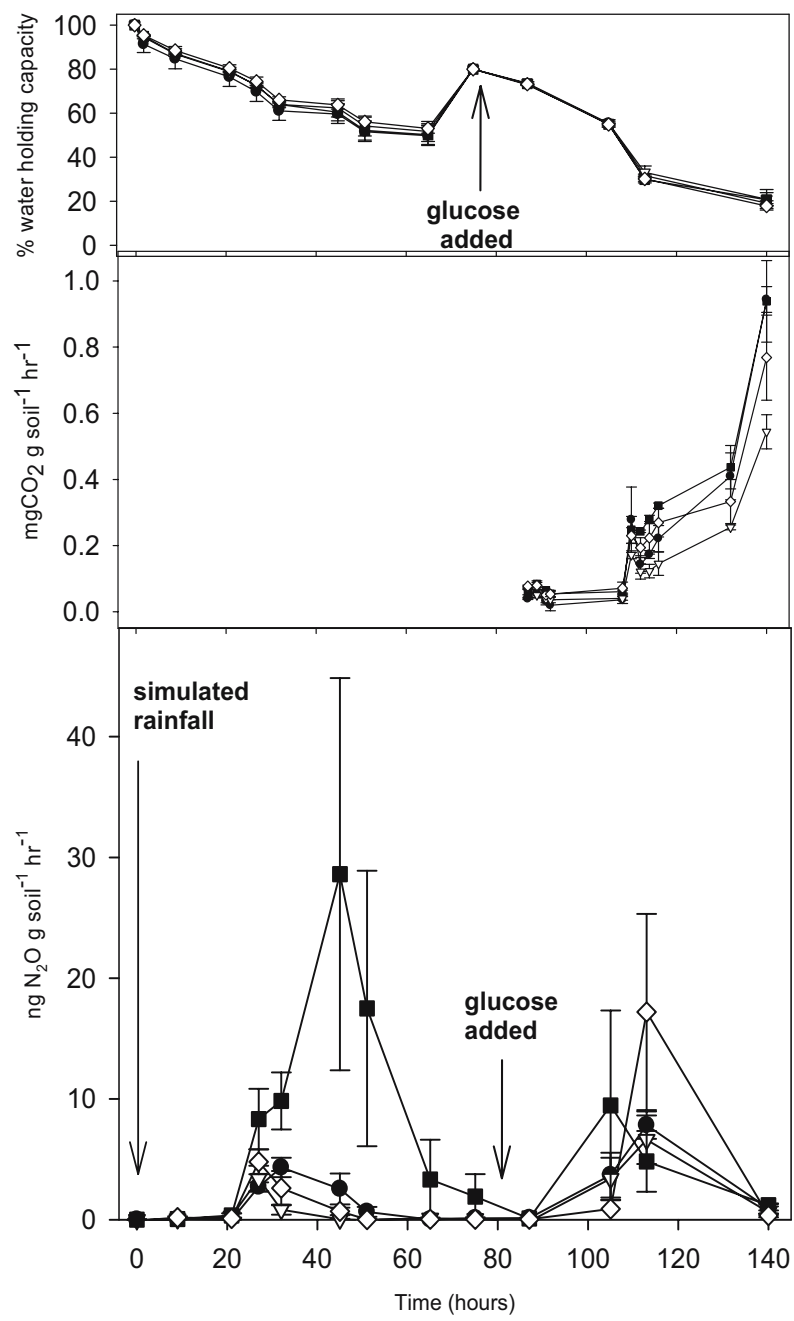

Fig. $2 \mathrm{~N}_{2} \mathrm{O}$ efflux after simulated rainfall event and soil $\mathrm{CO}_{2}$ and $\mathrm{N}_{2} \mathrm{O}$ efflux after glucose-based substrate addition $( \pm \mathrm{SE})$. Upper chart shows decline in soil moisture with drying. Symbols represent soils sampled from the following fallow treatments: •, A. colei; ', G. sepium; $\bullet$, traditional fallow; and $\nabla$, continuous cultivation

and thus $\mathrm{N}_{2} \mathrm{O}$ evolution, as discussed above. The importance of rainfall as a trigger of $\mathrm{NO}$ and $\mathrm{N}_{2} \mathrm{O}$ emissions from dry tropical soils has been demonstrated (Rondon et al. 1993) as well as the association with rainfall intensity. This study demonstrates that the addition of $\mathrm{C}$ and $\mathrm{N}$ substrates to the soil renews the pulse of $\mathrm{N}_{2} \mathrm{O}$ and $\mathrm{CO}_{2}$ emission. The release of $\mathrm{N}_{2} \mathrm{O}$ precedes the increase in soil respiration at $80 \%$ soil water content, which is consistent with the expectation that the anaerobic microbial community is most active in $\mathrm{N}_{2} \mathrm{O}$ release, while aerobic respiration and $\mathrm{N}_{2} \mathrm{O}$ evolution through nitrification occurs as the soil dries. The temporarily stable respiration rate that occurs after substrate addition is attributed to the oxidation of the glucose by enzymes already present in the soil sample, and the exponential increasing rate, $\mu$, to the respiration resulting from the consumption of the glucose by the growing micro-organism population (Stenström et al. 1998). Overall, the soil microbial biomass community was estimated to be most responsive to substrate addition in the G.sepium soils, where microbial biomass carbon was estimated to be significantly higher.

Some interesting aspects of soil $\mathrm{N}_{2} \mathrm{O}$ emission dynamics are suggested by this study: after the addition of substrate, a high pulse of $\mathrm{N}_{2} \mathrm{O}$ was observed from all the treatments except G. sepium, which was in contrast to the higher pulse from this treatment after the simulated rainfall event. The rapid $\mathrm{N}_{2} \mathrm{O}$ release of $G$. sepium in response to simulated rainfall suggests higher levels of denitrifying microbial communities in this soil, which quickly depleted the bioavailable $\mathrm{N}$ during the first pulse, while addition of glucose as a $\mathrm{C}$ substrate did not stimulate much further $\mathrm{N}_{2} \mathrm{O}$ emissions. Native levels of available $\mathrm{C}$ were perhaps higher in these soils as suggested by the SOC data. By contrast, low $\mathrm{N}_{2} \mathrm{O}$ emissions after the simulated rainfall were followed by a higher peak after addition of glucose, suggesting that the other treatments were $\mathrm{C}$-limited during the first pulse. Further research is required to dissect the interplay between nitrogen and carbon resources and the soil moisture control of gas fluxes from dry land soils.

This study demonstrates that selection of improved fallows for short-term fertility enhancement can improve crop yield in the succeeding years; however, foliar content of nitrogenous compounds and other nutrients in the incorporated tree biomass is an important factor in determining later crop improvement and sustained yields. Fertility enhancement by planting leguminous $\mathrm{N}$-fixing trees is also shown to have implications for $\mathrm{N}_{2} \mathrm{O}$ emissions. Greenhouse gas emissions from semi-arid agro-ecosystems need to be quantified to enhance the resolution of regional and national budgets for dry land areas. At present, climateforcing gas emissions are underestimated and crudely defined for dry land agro-ecosystems, and further research is needed to improve accounting systems for global cli-

Table 4 Microbial parameters calculated from substrate-induced respiration $( \pm \mathrm{SE})$

\begin{tabular}{|c|c|c|c|c|c|}
\hline & $\begin{array}{l}\mathrm{R}_{\mathrm{B}} \\
\mu \mathrm{gCO}_{2} \mathrm{~g}^{-}\end{array}$ & $\mathrm{R}_{\mathrm{S}}$ & $\mathrm{Q}_{\mathrm{R}}$ ratio & $\mu h^{-1}$ & $\begin{array}{l}\text { SMBC } \\
\mu \mathrm{g} \mathrm{C}^{-1} \text { soil }\end{array}$ \\
\hline G. sepium & $9.5 \pm 0.4^{\mathrm{a}}$ & $28.1 \pm 0.8^{\mathrm{a}}$ & $0.34 \pm 0.01^{\mathrm{b}}$ & $0.88 \pm 0.12^{\mathrm{a}}$ & $24.1 \pm 0.7^{\mathrm{a}}$ \\
\hline A. colei & $7.7 \pm 0.8^{\mathrm{a}}$ & $17.9 \pm 2.6^{\mathrm{a}, \mathrm{b}}$ & $0.43 \pm 0.02^{\mathrm{a}, \mathrm{b}}$ & $0.89 \pm 0.03^{\mathrm{a}}$ & $15.2 \pm 2.3^{\mathrm{a}, \mathrm{b}}$ \\
\hline Traditional fallow & $7.8 \pm 1.8^{\mathrm{a}}$ & $18.0 \pm 5.7^{\mathrm{a}, \mathrm{b}}$ & $0.46 \pm 0.05^{\mathrm{a}}$ & $0.62 \pm 0.14^{\mathrm{a}, \mathrm{b}}$ & $15.3 \pm 4.9^{\mathrm{a}, \mathrm{b}}$ \\
\hline Continuous culture & $6.6 \pm 0.9^{\mathrm{a}}$ & $13.0 \pm 2.6^{\mathrm{b}}$ & $0.52 \pm 0.03^{\mathrm{a}}$ & $0.51 \pm 0.05^{\mathrm{b}}$ & $10.9 \pm 2.3^{\mathrm{b}}$ \\
\hline
\end{tabular}

$R_{B}$ Basal rate of soil respiration, $R_{S}$ substrate-induced soil respiration, $Q_{R}$ respiratory activation quotient, $\mu$ growth rate of soil microbes, $S M B C$ soil microbial biomass carbon ( $\mu \mathrm{g} \mathrm{C} \mathrm{g}{ }^{-1}$ soil)

Different letters within columns indicate significant differences found using Fisher's protected least significant difference (LSD) test 
mate change modellers in particular. New guidelines for non- $\mathrm{CO}_{2}$ greenhouse gas monitoring required of projects launched under Articles 6 and 12 of the Kyoto protocol suggest use of generic levels specified for land in this climate zone by IPCC (2000), however the $\mathrm{N}_{2} \mathrm{O}$ emissions found in this study show that predicted levels could be considerably refined for different agricultural systems in semi-arid areas.

Acknowledgements This work was supported by funding from the United Nations Environment Programme (UNEP)/Global Environment Facility (GEF)/Desert Margins Program (GF/2711-02-4516). The authors would like to thank ICRISAT and ICRAF for their core funding which supported the fieldwork at Samanko. We thank Bryan Spears for providing ammonia analysis.

\section{References}

Albrecht A, Kandji ST (2003) Carbon sequestration in tropical agroforestry systems. Agric Ecosyst Environ 99:15-27

Allen SE, Grimshaw HM, Parkinson JA, Quarmby C (1974) Chemical analysis of ecological materials. Wiley, New York

Anderson JPE, Domsch KH (1978) A physiological method for the quantitative measurement of microbial biomass in soils. Soil Biol Biochem 10:215-221

Badiane NNY, Chotte JL, Pate E, Masse D, Rouland C (2001) Use of soil enzyme activities to monitor soil quality in natural and improved fallows in semi-arid tropical regions. Appl Soil Ecol 18:229-238

Baggs EM, Rees RM, Smith KA, Vinten AJA (2000) Nitrous oxide emission from soils after incorporating crop residues. Soil Use Manag 16:82-87

BS-ISO (2002) Soil quality. Determination of abundance and activity of soil microflora using respiration curves. In: BB Standards (ed) BS ISO 17155:2002. BSI, Geneva

Chikowo R, Mapfumo P, Nyamugafata P, Giller KE (2004) Mineral $\mathrm{N}$ dynamics, leaching and nitrous oxide losses under maize following two-year improved fallows on a sandy loam soil in Zimbabwe. Plant Soil 259:315-330

Dick J, Skiba U, Wilson J (2001) The effect of rainfall on NO and $\mathrm{N}_{2} \mathrm{O}$ emissions from Ugandan agroforest soils. Phyton-Ann Rei Bot 41:73-80

Dick J, Skiba U, Munro RC, Deans JD (2004) Effect of N-fixing trees and crops on $\mathrm{NO}$ and $\mathrm{N}_{2} \mathrm{O}$ emissions from Senegalese soils. J Biogeogr (in press)

Giller KE (2000) Translating science into action for agricultural development in the tropics: an example from decomposition studies. Appl Soil Ecol 14:1-3
Goering H, Van Soest P (1970) Forage fiber analysis. In: Agriculture handbook no. 379. ARS, USDA, Washington, DC

Ikerra ST, Maghembe JA, Smithson PC, Buresh RJ (2001) Dryseason sesbania fallows and their influence on nitrogen availability and maize yields in Malawi. Agrofor Syst 52:13-21

IPCC (2000) Land use, land-use change, and forestry. In: Watson RT, Noble IR, Bolin B, Ravindranath NH, Verardo DJ, Dokken DJ (eds) A special report of the Intergovernmental Panel on Climate Change. Cambridge University Press, Cambridge, UK

Kaya B, Nair PKR (2001) Soil fertility and crop yields under improved-fallow systems in southern Mali. Agrofor Syst 52:111

Mafongoya PL, Giller KE, Palm CA (1997) Decomposition and nitrogen release patterns of tree prunings and litter. Agrofor Syst 38:77-97

Millar N, Ndufa JK, Cadisch G, Baggs EM (2004) Nitrous oxide emissions following incorporation of improved-fallow residues in the humid tropics. Glob Biogeochem Cycles 1(18):GB1032

Okalebo JR, Gathua KW, Woomer PL (2002) Laboratory methods of soil and plant analysis: a working manual, 2nd edn. TSBF, Nairobi, Kenya, 128 p

Palm CA, Sanchez PA (1991) Nitrogen release from the leaves of some tropical legumes as affected by their lignin and polyphenolic contents. Soil Biol Biochem 23:83-88

Palm CA, Giller KE, Mafongoya PL, Swift MJ (2001) Management of organic matter in the tropics: translating theory into practice. Nutr Cycl Agroecosyst 61:63-75

Palm CA, Alegre JC, Arevalo L, Mutuo PK, Mosier AR, Coe R (2002) Nitrous oxide and methane fluxes in six different land use systems in the Peruvian Amazon. Glob Biogeochem Cycles 4 (16):GB1073

Rondon A, Johansson C, Sanheza E (1993) Emission of nitric oxide from soils and termite nests in a trachypogon savanna of the Orinoco basin. J Atmos Chem 17:293-306

Rowell DL (1994) Soil science: methods and applications. Longman, UK

Sileshi G, Mafongoya PL (2003) Effect of rotational fallows on abundance of soil insects and weeds in maize crops in eastern Zambia. Appl Soil Ecol 23:211-222

Snapp SS, Mafongoya PL, Waddington S (1998) Organic matter technologies for integrated nutrient management in smallholder cropping systems of southern Africa. Agric Ecosyst Environ 71:185-200

Stenström J, Stenberg B, Johansson M (1998) Kinetics of substrateinduced respiration (SIR): theory. Ambio 27:35-39

Talling JF, Lemoalle J (1998) Ecological dynamics of tropical inland waters. Cambridge University Press, Cambridge, UK

Wetzel RG, Likens GE (2000) Limnological analyses. Springer, Berlin Heidelberg New York 